\title{
Pengembangan Ayam Kampung Unggul Balitbangtan-1 (KUB) di Sumatera Utara
}

\section{Kampung Unggul Balitbangtan -1 (KUB) Chicken Development in North Sumatera}

\author{
Aulia Rahmad Hasyim¹, Khadijah El Ramija1, Khairiyah¹, Alwiyah² \\ ${ }^{1}$ BPTP Sumatera Utara (JIn. Jend. Besar A.H. Nasution No. 1B Medan 20143) \\ ${ }^{2}$ Loka Penelitian Kambing Potong (Sei Putih, PO Box 1 Galang 20585, Sungei Putih, \\ Galang,Kab. Deli Serdang 20585) \\ *Email Koresponden: aulianursyahhasyim@gmail.com
}

\begin{abstract}
Abstrak. Ayam KUB-1 merupakan ayam yang dihasilkan dari seleksi ayam kampung yang dilakukan oleh Balitnak. Ayam KUB-1 memiliki keunggulan berupa tingginya produksi telur. BPTP Sumatera Utara merupakan salah satu unit pelaksana teknis yang mengembangkan ayam KUB di Sumatera Utara. Sebagai kooperator adalah petani-peternak yang sudah ditentukan untuk peternak inti dan peternak plasma. Dilakukan Pembangunan kandang inti dan pembangunan kandang plasma.Ayam pullet KUB-1 populasi 500 ekor di kandang inti dan 250 ekor DOC didistribusikan ke kandang plasma 1 di Desa Galang Suka Kec. Galang Kab. Deli Serdang, Plasma 2 di Kelurahan Sari Rejo Kec. Medan Polonia Kota Medan dan Plasma 3 di Desa Pematang Cengal Barat Kec. Tanjung Pura Kab Langkat. Produktivitas produksi ayam KUB-1 di ketiga kandang tidak berbeda jauh hanya kandang Desa Galang Suka Kabupaten Deli Serdang lebih rendah jika dibandingkan dengan kandang Sari Rejo Kota Medan dan kandang Desa P.Cengal Kabupaten Langkat. Nilai IOFC terendah dimiliki oleh peternak yang berasal dari kandang plasma Desa Galang Suka, Kabupaten Deli Serdang dan nilai IOFC yang tertinggi adalah kandang plasma Desa P. Cengal Kabupaten Langkat.
\end{abstract}

Kata kunci: Ayam KUB-1, Strata II, Sumatera Utara

\begin{abstract}
KUB-1 chickens are chickens produced from the selection of free-range chickens carried out by Balitnak. The advantage of KUB-1 chicken has a high egg production rate. BPTP of North Sumatera is one of the technical implementing units that developed KUB chickens in North Sumatra. The distribution of KUB-1 chickens in North Sumatra has been well-received by people all around regions between cities. The development of the Strata-II Research and Development Agency KUB-1 in North Sumatra is carried out in a participatory manner by involving farmers. As cooperators are farmers who have been determined to be core breeders and plasma farmers. Construction of core cages and construction of plasma cages were carried out. KUB pullet chickens with a population of 500 in the core cage and 250 DOCs were distributed to plasma cages 1 in Galang Suka Village, Kec. Galang Kab. Deli Serdang, Plasma 2 in Sari Rejo Village, Kec. Medan Polonia, Medan City and Plasma 3 in Pematang Cengal Barat Village, Kec. Tanjung Pura, Langkat Regency. The productivity of KUB chicken production in the three cages did not differ much, only the cage in Galang Suka Village, Deli Serdang Regency, was lower than the Sari Rejo cage in Medan City and the P.Cengal Village cage, Langkat Regency. The lowest IOFC value was owned by farmers who came from plasma cages in Galang Village. Suka, Deli Serdang Regency and the highest IOFC value is the plasma cage in P. Cengal Village, Langkat Regency.
\end{abstract}


Hasyim et. al.

ANIMPRO: Conference of Applied Animal Science Proceeding Series

Keywords: KUB-1 Chicken, Strata II, North Sumatera

\section{PENDAHULUAN}

Kebutuhan konsumsi protein di Indonesia mencapai 5.8 gram/kapita/hari (Ditjen PKH 2018), hal tersebut masih dikaakan rendah. Untuk itu konsumsi protein hewani perlu ditingkatkan dengan cara penyediaan pangan hewani salah satunya adalah ternak unggas. Ternak unggas yang dapat diandalkan sebagai penyuplai protein hewani adalah ayam Kampung, karena sistem pemeliharaannya dapat dikatakan mudah dan sederhana dan dapat diaplikasikan ke semua lapisan masyarakat. Rumpun ayam kampung sangat beragam di Indonesia dan sudah adaptif dengan berbagai lingkungan tropis. Dari rumpun yang terbentuk ini sangat potensial untuk dikembangkan dan dimanfaatkan sebagai pemenuhan kebutuhan protein hewani masyarakat (Sartika et al., 2013).

Balai Penelitian Ternak, Balitbang Pertanian menghasilkan ayam kampung unggul bernama Ayam KUB-1 yang merupakan ayam kampung galur murni. Ayam KUB-1 memiliki keunggulan berupa produksi telur tinggi yaitu produksi telur henday $45-50 \%$, puncak produksi telur mencapai 84\% pada umur ayam 31 minggu, bobot telur pertama bertelur $30 \mathrm{gr} / \mathrm{butir}$, dan akan bertambah terus sampai $36 \mathrm{gr} /$ butir pada akhir bulan kedua berproduksi (Sartika et al., 2016). Budidaya ayam KUB-1 sudah banyak di kembangkan di masyarakat khususnya di Sumatera Utara baik secara tradisional maupun modern namun belum usaha secara bisnis.

Balai Pengkajian Teknologi Pertanian (BPTP) Sumatera Utara adalah salah satu Unit Pelasana Teknis (UPT) dari Badan Penelitian dan Pengembangan Pertanian, yang ada di daerah untuk mentransfer teknologi pertanian. Perbibitan ayam KUB-1 melalui UPBS (Unit Perbibitan Benih Sumber) ayam KUB-1 yang telah didirikan sejak tahun 2018 menjadi sangat penting dalam mendukung ketahanan pangan. Pemeliharaan ayam KUB-1 dilakukan sebagai bentuk dukungan terhadap terpenuhinya kebutuhan protein hewani masyarakat di Sumatera Utara. Salah satu tujuan dari tulisan ini adalah untuk memberikan informasi peran dan pengembangan Ayam KUB1 dalam mendukung ketahanan pangan khususnya protein hewani dan pengembangan di Sumatera Utara

\section{MATERI DAN METODE}

Penelitian ini dilaksanakan dengan menggunakan metode survei. Responden terdiri atas peternak ayam KUB-1 yang berada di tiga wilayah plasma yaitu kandang plasma 1 di Desa Galang Suka Kec. Galang Kab. Deli Serdang, Plasma 2 di Kelurahan Sari Rejo Kec. Medan Polonia Kota Medan dan Plasma 3 di Desa Pematang Cengal Barat Kec. Tanjung Pura Kab Langkat. Data penelitian terdiri atas data primer yang diperoleh melalui wawancara responden dan data sekunder yang diperoleh melalui referensi. Data yang diperoleh dari penelitian ini adalah jumlah ayam, jumlah ayam terpanen, tonase, rataan bobot badan, deplesi, total pakan, FCR, dan Nilai IOFC.

\section{HASIL DAN PEMBAHASAN}

Penyebaran Ayam KUB-1 di Sumatera Utara

Ayam KUB-1 yang dimiliki oleh BPTP Sumatera Utara sudah terdistribusi dengan baik ke berbagai daerah antar kota bahkan antar provinsi. Peta sebaran distribusi ayam KUB BPTP Sumatera utara terdapat pada Gambar 1. 

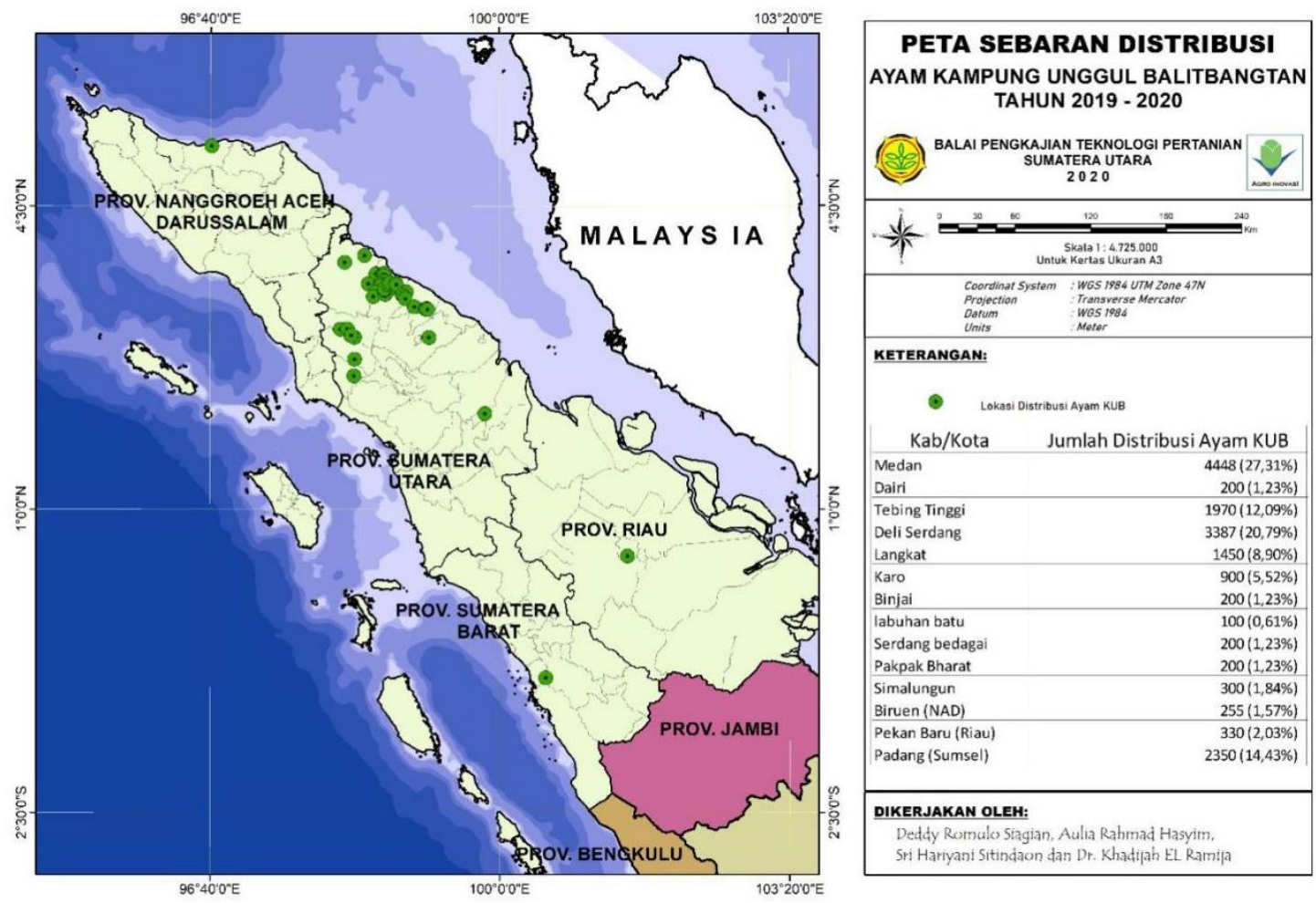

\section{Gambar 1. Peta Sebaran distribusi Ayam KUB-1 BPTP Sumut.}

Peta sebaran ayam KUB-1 yang berasal dari BPTP Sumatera Utara mencakup beberapa daerah diantaranya Medan, Dairi, Tebing Tinggi, Deli Serdang, Langkat, Karo, Binjai, Labuhan Batu, Serdang Bedagai, Pakpak Bharat, Simalungun, Bireun (NAD), Pekan Baru dan Padang. Data sebaran distribusi menunjukkan bahwa $81,97 \%$ dari total ayam KUB-1 tersebut masih terkonsentrasi di wilayah Provinsi Sumatera Utara. Hal ini mengisyaratkan bahwa masih tingginya antusias peternak dalam mengembangkan ayam KUB-1 ini. Penyebaran ayam KUB-1 dilakukan baik oleh pemerintah daerah setempat dan masyarakat yang ingin belajar beternak ayam KUB-1 untuk merintis usaha ternak. Pengiriman ayam KUB-1 ke berbagai daerah ini tentunya memperhatikan protokol pengiriman. Pengiriman ke luar wilayah Sumatera Utara disertakan dengan surat izin yang diberikan oleh Badan Karantina Pertanian setempat untuk dilakukan pengujian. Pengiriman ayam KUB-1 ke berbagai daerah di Sumatera Utara menggunakan jalur darat dengan memperhatikan kesejahteraan ternak selama perjalanan, seperti memberikan makan dan minum, memberikan vitamin anti stres, serta memperhatikan sirkulasi udara di kandang ayam yang dibawa.

\section{Pengembangan Ayam KUB-1 Model Strata - II}

Pemeliharaan ayam kampung dengan sistem tradisional menyebabkan produktivitas rendah dan tingkat mortalitas tinggi. Ayam kampung pada umumnya (80\%) dipelihara secara ektensif sebagai usaha sampingan dengan sistem umbaran (mencari makan sendiri) dan sisanya $(20 \%)$ dipelihara secara semi intensif dan intensif. Teknologi pemeliharaan merupakan faktor yang menentukan keberhasilan dalam usaha ayam Kampung yang meliputi: perbibitan, pakan, dan pengendalian penyakit. (Roosganda, 2012).

Ayam Kampung Unggul Badan Litbang atau disingkat Ayam KUB merupakan hasil seleksi Balai Penelitian Ternak-Bogor sebagai salah satu upaya untuk mengatasi permasalahan 
produktifitas ternak ayam kampung yang masih rendah. Ayam KUB-1 memiliki beberapa keunggulan jika dibandingkan dengan ayam kampung biasa. Berbagai kelebihannya antara lain: Produksi telur ayam KUB-1: $45-50 \%$ dibanding ayam kampung biasa hanya $20 \%$ pada pemeliharaan semi intensif, 30\% pada pemeliharaan Intensif; Puncak produksi telur mencapai 84\% pada umur ayam 31 minggu, bobot telur pertama bertelur seberat 35-36 gram, akan bertambah terus sampai $45 \mathrm{gram} / \mathrm{butir}$ pada akhir bulan kedua berproduksi. Produktivitas telur lebih tinggi/tahun, yaitu 160-180 butir; Umur pertama bertelur lebih awal (20-22 minggu); Konsumsi pakan $80-85$ gram; Sifat mengeram 10\% dari total populasi, dan bobot badan bisa mencapai 1.200-1.600 gram.

Pengembangan ayam KUB-1 yang berkelanjutan dapat dilakukan melalui suatu sistem yang berkesinambungan dari hulu sampai hilir, yaitu usaha produksi DOC dan indukan ayam KUB-1, usaha pembesaran ayam KUB-1 untuk produksi daging, dan, usaha pengolahan/penanganan pasca panen. Salah satu komponen produksi yang dibutuhkan peternak adalah bibit ternak bermutu (unggul). Ketersediaan bibit unggul sangat strategis, karena menjadi penentu batas atas produksi ternak. Oleh karena itu diperlukan upaya peningkatan inovasi untuk memperbesar pasokan bibit unggul, memperbaiki sistem distribusi dan meningkatkan bibit unggul melalui pengembangan sistem perbibitan ternak nasional. Produksi ternak di dalam negeri memerlukan dorongan dari hasil pemuliaan. Namun demikian sampai dengan saat ini, sebagian besar kegiatan pemuliaan masih terkonsentrasi di lembaga penelitian atau unit pelaksana teknis perbibitan milik pemerintah yang kapasitasnya sangat terbatas. Oleh karena itu untuk dapat meningkatkan kapasitas penyediaan bibit ternak unggul, diperlukan peran pemerintah maupun swasta, yang dapat dilakukan melalui mekanisme kerjasama perbanyakan bibit ternak.

Dalam mengembangkan pembibitan ternak, perlu adanya kerja sama dan interaksi yang kuat antara pemerintah dan kelompok Petani/Peternak. Hal ini dikarenakan individu masyarakat mempunyai pola pikir yang berbeda-beda, sehingga perlu kesadaran untuk mendukung terlaksananya suatu kegiatan. Salah satu langkah strategis untuk memenuhi kebutuhan bibit ternak adalah dengan membentuk, membina dan mengembangkan pembibitan ternak rakyat (Village Breeding Centre atau VBC). Dengan adanya pembibitan ternak rakyat ini diharapkan mampu mengembangkan peternakan secara berkelanjutan.

Metode yang digunakan dalam pengembangan ayam Kampung Unggul Badan Litbang (KUB1) Strata-II di Sumatera Utara dilakukan secara partisipatif dengan melibatkan peternak. Sebagai kooperator adalah petani-peternak yang sudah ditentukan untuk peternak inti dan peternak plasma. Dilakukan Pembangunan kandang inti dan pembangunan kandang plasma (Gambar 2).

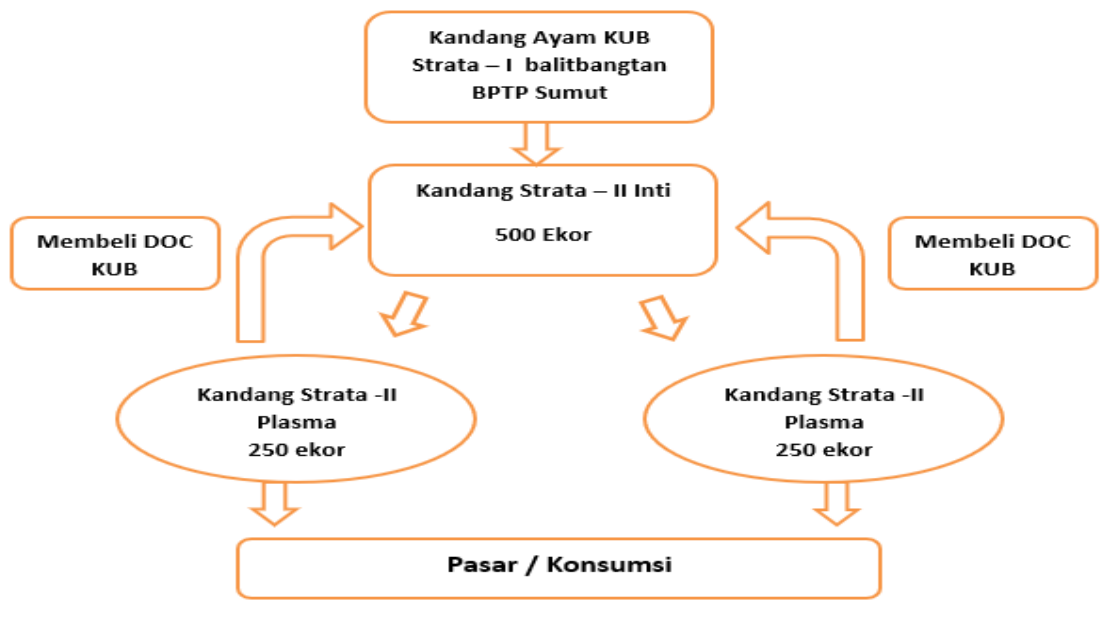

Gambar 2. Diagram Alur Pengembangan Ayam KUB Strata-II di Sumatera Utara 
Hasyim et. al.

ANIMPRO: Conference of Applied Animal Science Proceeding Series

\section{Produktivitas Ayam KUB-1 di Kandang Plasma}

Ayam pullet KUB-1 populasi 500 ekor di kandang inti dan 250 ekor DOC didistribusikan ke kandang plasma 1 di Desa Galang Suka Kec. Galang Kab. Deli Serdang, Plasma 2 di Kelurahan Sari Rejo Kec. Medan Polonia Kota Medan dan Plasma 3 di Desa Pematang Cengal Barat Kec. Tanjung Pura Kab Langkat. Sebelumnya dilakukan bimbingan teknis pemeliharaan kepada peternak. Berikut ini adalah tabel produktivitas ayam KUB-1 kandang Plasma (Tabel 1).

Tabel 1. Produktivitas ayam KUB-1 kandang Plasma umur 0-16 minggu

\begin{tabular}{lccc}
\hline Parameter & $\begin{array}{c}\text { Kandang Desa Galang } \\
\text { Suka Kab Deli Serdang }\end{array}$ & $\begin{array}{c}\text { Kandang Desa Sari } \\
\text { Rejo Kota Medan }\end{array}$ & $\begin{array}{c}\text { Kandang Desa P. } \\
\text { Cengal Kab. Langkat }\end{array}$ \\
\hline $\begin{array}{l}\text { Jumlah Chick in / } \\
\text { ekor }\end{array}$ & 250 ekor & 250 ekor & 250 ekor \\
Jumlah Ayam & 218 ekor & 223 ekor & 220 ekor \\
Terpanen & & & \\
& & & \\
Tonase & $269,44 \mathrm{Kg}$ & $302,7 \mathrm{Kg}$ & $321,2 \mathrm{Kg}$ \\
Abw / Kg & $1,23 \mathrm{Kg}$ & $1,35 \mathrm{Kg}$ & $1,46 \mathrm{Kg}$ \\
Deplesi & $12,8 \%$ & $10,8 \%$ & $12 \%$ \\
Total Pakan & $1390 \mathrm{Kg}$ & $1520 \mathrm{Kg}$ & $1740 \mathrm{Kg}$ \\
FCR & 5,15 & 5,02 & 5,41 \\
\hline
\end{tabular}

Produktivitas produksi ayam KUB-1 di ketiga kandang tidak berbeda jauh hanya kandang Desa Galang Suka Kabupaten Deli Serdang lebih rendah jika dibandingkan dengan kandang Sari Rejo Kota Medan dan kandang Desa P.Cengal Kabupaten Langkat. Jumlah ayam yang terpanen dari ketiga kandang plasma, yang paling tinggi adalah kandang Desa Sari Rejo Kota Medan. Namun untuk tonase dan rataan bobot ayam yang tertinggi adalah Kandang Desa P. Cengal Kabupaten Langkat. Deplesi dan tingkat efisiensi ransum (FCR) ayam KUB-1 yang terendah terdapat di kandang Desa Sari Rejo Medan yaitu 10,8\% dan 5,02. Menurut Kusnadi (2006), besarnya tingkat deplesi dipengaruhi oleh beberapa faktor diantaranya; bobot badan, suhu lingkungan, kebersihan lingkungan serta penyakit, sanitasi peralatan kandang dan manajemen pemeliharaan. Namun ketiga kandang tersebut memiliki nilai FCR yang cukup tinggi jika dibandingkan dengan pemeliharaan ayam KUB-1 di lingkungan kantor BPTP Sumatera Utara. Siregar (2005) menyatakan bahwa konversi pakan dipengaruhi oleh beberapa faktor yaitu genetik, bentuk pakan, temperatur, lingkungan, konsumsi pakan, berat badan, dan jenis kelamin.

Analisis Income Over Feed Cost (IOFC) ditujukan untuk melihat keuntungan dari suatu pendapatan yang diterima ketika beternak ayam KUB-1. Harga ransum yang digunakan merupakan harga ransum yang berlaku pada saat itu. Keuntungan yang diperoleh dengan menghitung selisih pendapatan usaha peternakan dikurangi biaya ransum. Pendapatan merupakan perkalian antara produksi peternakan atau pertambahan bobot badan akibat perlakuan dengan harga jual (Nova et al., 2002). Nilai IOFC rata-rata dari ketiga kandang plasma (Tabel 2) berkisar 1.65-1.87 nilai tersebut menunjukkan bahwa setiap Rp.1 yang dikeluarkan untuk produksi ayam KUB-1, mendapat Rp.0.65-0.87. Menurut Rasyaf (2011) menyatakan bahwa semakin tinggi nilai IOFC akan semakin baik pula pemeliharaan yang dilakuan, karena tingginya IOFC berarti penerimaan yang didapat dari hasil penjualan ayam juga semakin tinggi. Sedangkan nilai IOFC terendah dimiliki oleh peternak yang berasal dari kandang plasma Desa Galang Suka, Kabupaten Deli Serdang dan nilai IOFC yang tertinggi adalah kandang plasma Desa P.Cengal Kabupaten Langkat. Adanya perbedaan nilai IOFC di berbagai kandang plasma disebabkan oleh adanya perbedaan manajemen pemeliharaan. Nilai IOFC juga sangat bergantung pada nilai konversi pakan. IOFC dihitung dengan mengetahui harga pakan perlakuan, banyaknya konsumsi pakan dan harga jual produksi (Sulistyani, 2015) Sari et al. (2017) menyatakan bahwa iofc ayam KUB-1 berkisar 1.69-1.82. 
Hasyim et. al.

ANIMPRO: Conference of Applied Animal Science Proceeding Series

Tabel 2. IOFC penjualan hidup Ayam KUB-1 kandang Plasma Strata - II Sumatera Utara Plasma Rataan BB Akhir Penerimaan Biaya Pakan IOFC

\begin{tabular}{|c|c|c|c|c|}
\hline \multirow[t]{2}{*}{ Plasma } & Rataan BB Akhir & Penerimaan & Biaya Pakan & IOFC \\
\hline & $\mathrm{Kg} /$ Ekor & \multicolumn{2}{|c|}{ Rp/ Ekor } & \\
\hline $\begin{array}{l}\text { Desa Galang } \\
\text { Suka Kab Deli } \\
\text { Serdang }\end{array}$ & 1,23 & Rp 55.350 & Rp 33.475 & $\begin{array}{c}\text { Rp } 21.875 \\
(1.65)\end{array}$ \\
\hline $\begin{array}{l}\text { Kandang } \\
\text { Desa Sari } \\
\text { Rejo Kota } \\
\text { Medan }\end{array}$ & 1,35 & Rp 60.750 & Rp 32.630 & $\begin{array}{c}\operatorname{Rp} 28.120 \\
(1,86)\end{array}$ \\
\hline $\begin{array}{l}\text { Kandang } \\
\text { Desa } \\
\text { P.Cengal Kab. } \\
\text { Langkat }\end{array}$ & 1,46 & Rp 65.700 & Rp 35.165 & $\begin{array}{c}\text { Rp } 30.535 \\
\quad(1.87)\end{array}$ \\
\hline
\end{tabular}

Potensi Pegembangan Ayam KUB-1 di Sumatera Utara

Ayam KUB-1 memiliki potensi yang sangat baik untuk dikembangkan di Sumatera Utara baik pemeliharaan yang dilakukan pribadi maupun kelompok. Pemeliharaan ayam KUB-1 yang sederhana, mudah dipelihara dan amemiliki daya adaptasi yang tinggi terhadap lingkungan membuat peternak rakyat berbondong-bondong untuk mendapatkan ayam KUB-1. Di Sumatera Utara permintaan akan ayam KUB-1 sangat tinggi yaitu sekitar 33.000 ekor DOC, namun permintaan ini terpenuhi hanya 22.000 saja. Hal ini terjadi karena masyarakat sangat tertarik dengan ayam KUB-1.

Pengembangan Ayam KUB-1 ini dapat dilakukan dengan model pengembangan kelompok dan membentuk kelembagaan manajemen pemeliharaan, sehingga pengelolaaan telur dan penetasan lebih mudah pembimbingannya. Ketersediaan kebutuhan pakan ayam KUB-1 pun melimpah di Sumatera Utara. Pemasaran hasil produk berupa daging ayam kampung sangat diminati di masyarakat.

Perencanaan kedepan pengembangan ayam KUB-1 yang akan dilakukan oleh BPTP Sumut yaitu akan mulai meningkatkan produki DOC ayam KUB-1 dan akan membuat pabrik pakan mini yang mampu menunjang kebutuhan pakan ayam KUB-1. Sehingga ke depannya nanti masyarakat tidak hanya dapat memperoleh DOC saja tapi pakan yang berkualitas juga dapat dikembangkan di masyarakat.

\section{KESIMPULAN}

Pemeliharaan ayam KUB-1 di BPTP Sumatera Utara memiliki potensi besar untuk dikembangkan untuk produksi telur, bibit ataupun daging. Namun pengembangan ayam KUB-1 di ketiga daerah tersebut masih perlu perbaikan pemiliharaan sehingga produksi ayam KUB-1 bisa lebih optimal lagi dan menguntungkan masyarakat setempat.strategi upaya yang dapat dilakukan untuk pengembangan adalah dengan menigkatkan populasi, produksi, produktivitas dan efisiensi usaha, serta perlu adanya dukungan teknologi pakan dan pencegahan pengendalian penyakit dengan menjaga kebersihan dan sanitasi kandang serta lingkungannya.

\section{DAFTAR PUSTAKA}

Direktorat Jenderal Peternakan dan Kesehatan Hewan. (2017). statistik peternakan dan kesehatan hewan. Jakarta: Direktorat Jenderal Peternakan dan Kesehatan Hewan Kementrian Pertanian RI.

Kusnadi, E. (2006). Suplementasi Vitamin C Sebagai Penangkal Cekaman Panas Pada Ayam Broiler. JITV Vol 11 No 4. Fakultas Peternakan Universitas Andalas. Padang.

Nova, K., T. Kurtini, dan Riyanti. (2002). Buku Ajar. Mnejemen Usaha Ternak Unggas. Universitas lampung. Bandar Lampung. 
Hasyim et. al.

ANIMPRO: Conference of Applied Animal Science Proceeding Series

Priyanti A, Sartika T, Priyono, Juliyanto TB, Soedjana TD, Bahri S, Tiesnamurti B. (2016). Kajian ekonomik dan pengembangan inovasi ayam Kampung Unggul Balitbangtan (KUB). Bogor (Indonesia): Puslitbangnak.

Rasyaf, M. (2011). Panduan Beternak Ayam Pedaging. Cetakan ke-4. Penebar Swadaya. Jakarta Sartika, T, Desmayati, S Iskandar, H Resnawati, A R Setiko, Sumanto, Arnoid P Sinurat, Isbandi, Bess, Endang. (2013). Ayam KUB-1. IAARD Press. Jakarta

Siregar, A.P., dan Sabrani. (2005). Teknik Beternak Ayam Pedaging di Indonesia. Magie Group. Jakarta.

Sulistyani. (2015). Pengaruh Penggunaan Tepung Kulit Buah Pepaya (Carica Papaya L) dalam Pakan terhadap Penampilan Produksi Ayam Pedaging. Skripsi. Fakultas Peternakan. Universitas Brawijaya. Malang 